\title{
POLYMORPHISM OF GENES ASSOCIATED WITH THE QUANTITATIVE TRAIT LOCI IN WILD BOAR (Sus scrofa L., 1758) IN RUSSIA
}

\author{
N.A. Zinovieva ${ }^{1}$, O.V. Kostyunina ${ }^{1}$, A.V. Ekonomov' ${ }^{2}$ M.S. Shevnina', \\ I.A. Domskij', E.A. Gladyr'1, G. Brem ${ }^{3}$ \\ ${ }^{1}$ All-Russia Research and Development Institute for Livestock Husbandry, RAAS, Dubrovitsy settlement 142132, Moscow province, Russia \\ e-mail: $n$ zinovieva@mail.ru \\ ${ }^{2}$ B.M. Zhitkov All-Russia Research and Development Institute of Hunting Economy and Fur Farming, RAAS, Kirov 610000, Russia \\ e-mail:vniioz@mail.ru \\ ${ }^{3}$ Veterindrmedizinische Universitdt, Vienna A-1210, Austria, \\ e-mail: gottfried.brem@agrobiogen.de
}

Received January 19, 2013

Sum mary

The genetic studies of wild boar (Sus scrofa L., 1758) $(n=89)$ inhabited in Russia using ten DNA markers RYR1, ESR, FSHB, NCOA1, $B F$, MUC4, IGF2, MC4R, POU1F1, ECRF18/FUT1 were carried out. The assignment of individuals to different territorial clusters was performed based on similarity coefficient $(Q)$ calculation for $k=2$. The average $Q$ values in individuals inhabited on European part and in East Siberian was $0.984 \pm 0.005$ and in Irkutsk region and Khabarovsk Kraj was 0.994 \pm 0.001 . Five DNA markers (RYR1, ESR, MUC4, IGF2, ECRF18/FUT1) were monomorphic in both of territorial clusters. The non-significant differences in allele frequencies of $F S H B, B F, M C 4 R$ and $P O U 1 F 1$ genes between individuals assigned to the west and east clusters were observed: $\mathrm{p}_{\mathrm{A}}=0.462$ and $0.250, \mathrm{p}_{\mathrm{A}}=0.020$ and $0.143, \mathrm{p}_{\mathrm{A}}=0.013$ and $0.000, \mathrm{p}_{\mathrm{C}}=0.000$ and 0.111 , respectively. The studied territorial groups significantly differed in $N C O A 1$ allele frequencies: $\mathrm{p}_{\mathrm{A} 1}=0.938$ in wild boars assigned to the west cluster and $p_{A 1}=0,000$ to the east cluster.

Keywords: wild boar, DNA markers, polymorphism, RYR1, ESR, FSHB, NCOA1, BF, MUC4, IGF2, MC4R, POU1F1, ECRF18/FUT1.

Wild boar is a widespread representative of wild mammals. Phenotypic differences of Sus scrofa L. allow distinguishing four races of pigs (Western, Eastern, Indian and Indonesian), which, in turn, include 16 (1), or, to some view, 27 subspecies (2, 3).

In Russia, according to A.A. Danilkin (4), there are five native subspecies of wild boar: Central European (S. s. Scrofa L., 1758), Caucasian (S. s. Attila Thorn, 1912), Siberian (S. s. Sibiricus Staffe, 1922), Central Asian (S. s. nigripes Blanf, 1875), and Ussuri (S. s. ussuricus Heude, 1888). These subspecies inhabit the territories with no clear boundaries owing to natural dispersion of animals, seasonal migrations associated with feed resources, floods, dynamics in height of the snow cover, altitudinal migrations, etc. One of the most important factors that change genetic structure of subspecies is acclimatization. For example, Ussuri subspecies known as the largest wild boar was introduced in European part of Russia, for example, in the hunting reserve "Zavidovo" (Tver oblast) $(5,6)$. Introduction of wild pigs is plasticized in the present as well.

In recent years, genetic diversity of populations of wild pigs is being actively investigated in many countries including Russia (7-9), and these researches have both scientific and practical value.

The achievements of molecular genetics open up new possibilities for studying animal groups and their genetic differentiation. For wild boar, these methods may reveal the extent of genetic introgression of domestic pig resulting from accidental hybridization. This can be performed using different types of DNA markers: mtDNA (10), microsatellites (11), SNP-markers (12, 13), and DNA markers associated with quantitative trait loci (14). The fact that domestic pigs were among the maternal ancestors of wild boars is proved by the presence of Asian mtDNA haplotype (A) identified in domestic pig breeds with a frequency of $29 \%$ (10) owing to historical introgression in XVII-XIX centuries from Chinese pigs (15), while the animals of "pure" European populations have only E1 and E2 haplotypes. Along with it, the introgression of domestic pigs into populations of wild boar can be assessed by the frequency of genes associated with quantitative trait loci (QTL). The frequency of $Q$ allele of IGF2 gene (mutation G3072A) associated with enhanced growth of muscle tissue and meat quality in commercial pig breeds was found to be equal $86 \%$, in local $3 \%$, and it was absent in 120 tested European wild boars (14). Y. Kuril et al. (16) characterized polymorphism of genes RYR1, LEP, $G H, M Y O G, M Y F 5$, and GDF8 in boars from the north-east of Poland. In this population, genes RYR1, LEP, and MYF5 were monomorphic, while $M Y O G, G H$, and $G D F 8$ were polymorphic with frequencies of alleles, respectively, 0,42 (allele $A$ ) and 0,58 (allele $B$ ); 0,56 (allele "+") and 0,44 (allele “-"); 0,63 (allele $C$ ) and 0,37 (allele $T$ ). In Asian and European populations, in was observed the segregation of different $M C 1 R$ alleles responsible for skin color and difference in color between wild boars and domestic pigs (6), which was used in the study of introgression in wild boars of Greece (7).

The purpose of this research was identification of the polymorphism of genes associated with QTLs in different groups of wild boar native in the territory of Russia.

Technique. The studied samples of muscle tissue were derived from wild pigs in different populations on the territory of Russia $(n=89)$ : Arkhangelsk oblast $(n=3)$, Bashkortostan $(n=3)$, Vladimir oblast $(n=3)$, Volgograd oblast $(n=5)$, Vologda oblast $(n=2)$, Ivanovo oblast $(n=3)$, Irkutsk oblast $(n=2)$, Kaliningrad oblast $(n=3)$, Kirov oblast $(n=8)$, Komi Republic $(n=1)$, Krasnodar krai $(n=1)$, Kurgan oblast $(n=3)$, Kursk oblast $(n=3)$, Leningrad oblast $(n=8)$, Mari-El Republic $(n=3)$, Nizhny Novgorod oblast $(n=4)$, Omsk oblast $(n=3)$, Orenburg oblast $(n=3)$, Penza oblast $(n=3)$, Saratov oblast $(n=1)$, Sverdlovsk oblast $(n=3)$, Smolensk oblast $(n=3)$, Tambov oblast $(n=4)$, the Republic of Tatarstan $(n=1)$, Tver oblast $(n=3)$, Udmurt Republic $(n=$ $2)$, Khabarovsk krai $(n=7)$, and the Republic of Chuvashia $(n=1)$.

DNA was isolated using Nexttec columns and DNA extraction kit DIAtom ${ }^{\text {TM }}$ DNA Prep100 ("Biokom”, Russia) following the manufacturers' recommendations.

Genetic clustering of the animals was performed based on the analysis of 12 microsatellites (17) with subsequent cluster 
analysis according to J.K. Pritchard et al. (18). The data were statistically processed in Structure software (v. 2.3.1) without the introduction of prior data about individual relations to particular groups for the number of populations (K-clusters), equal to 2.

The used DNA markers of QTL: ryanodine receptor gene (RYRI), estrogen receptor $(E S R)$, $\beta$-subunit of follicle stimulating hormone $(F S H B)$, coactivator of steroid hormones (NCOA1), properdin $(B F)$, mucin 4 (MUS4), insulin-like growth factor 2 (IGF2), melanocortin receptor $4(M C 4 R)$, pituitary transcriptional factor (POU1F1), receptor Escherichia coli (ECRF18/FUT1). Polymorphism of these genes was determined using the techniques developed in the Center for Biotechnology and Molecular Diagnostics (All-Russia Research and Development Institute for Livestock Husbandry).

The obtained information about alleles of each animal was summarized in Microsoft Excel spreadsheet. The resulting matrix of genotypes was statistically processed by standard methods $(19,20)$.

Results. The analysis of genetic structure of the studied total sample group of wild boars for $\mathrm{k}=2$ (Fig. 1) revealed a marked genetic differentiation of individuals in two clusters: conditionally western (hereinafter - the first cluster) and eastern (second one). The first includes the animals from the Central Russia, the Caucasus, Urals, and the Western Siberia, the second - from Khabarovsk Krai and Irkutsk region.

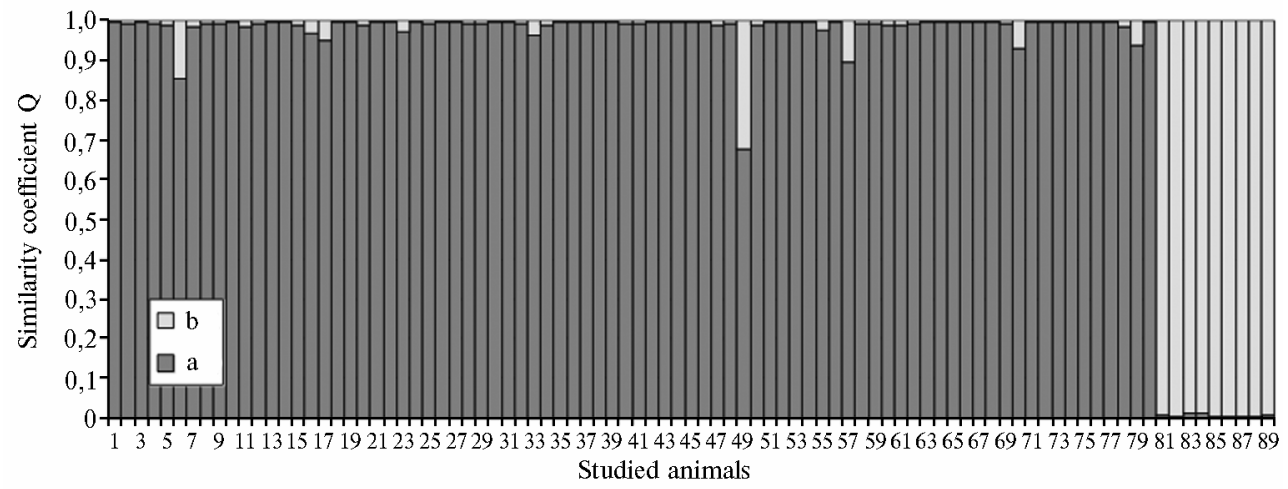

Fig. 1. Genetic structure of the studied groups of wild boar (Sus scrofa L., 1758) for 10 DNA-markers QTL: 1-3 — animals from Arkhangelsk oblast, 4-6 — from Bashkortostan, 7-9 — Vladimir oblast, 10-14 Volgograd oblast, 15-16 — Vologda oblast, 17-19 — Ivanovo oblast, 20-22 — Kaliningrad oblast, 23-30 - Kirov oblast, 31 - Komi Republic, 32 - Krasnodar krai, 33-35 — Kurgan oblast, 36-38 - Kursk oblast, 39-46 Leningrad oblast, 47-49 - Mari El Republic, 50-53 - Nizhny Novgorod oblast, 54-56 - Omsk oblast, 57-59 Orenburg oblast, 60-62 - Penza oblast, 63 - Saratov oblast, 64-66 - Sverdlovsk oblast, 67-69 - Smolensk oblast, 70-73 - Tambov oblast, 74 — Republic Tatarstan, 75-77 — Tver oblast, 78-79 — Udmurt Republic, 80 — Republic Chuvashia, 81-82 — Irkutsk oblast, 83-89 - Khabarovsk krai; a - Q $\mathrm{Q}_{1}$, b - Q Q $_{2}$ Calculations performed according to J.K. Pritchard et al. (18) for $\mathrm{k}=2$. Description of markers - see "Technique".

Average value of similarity coefficient (Q) of wild boars from the European Russia and Western Siberia in the first group was equal to $Q_{1}=0,984 \pm 0,005$ with individual variations from 0,679 to 0,998 . In 78 of the 80 tested animals $Q_{1}$ exceeded 0,900 , and only two animals from Mari El Republic and Bashkortostan showed $\mathrm{Q}_{1}$ of, respectively, 0,679 and 0,855, possibly, due to introgression of ancestors from the second cluster. In wild boars of Irkutsk oblast and Khabarovsk krai, average value of $\mathrm{Q}$ was equal to $\mathrm{Q}_{2}=$ $0,994 \pm 0,001$ with variations from 0,989 to 0,997 . Thus, the obtained data allow the conclusion about reliable genetic differences between animals of these two clusters.

Frequency of genotypes in respect to DNA-markers QTL over the studied total sample of wild boar (Sus scrofa L., 1758)

\begin{tabular}{|c|c|c|c|}
\hline Genotype, cluster & \multicolumn{3}{|c|}{ Frequency of genotype, $\%$} \\
\hline \multicolumn{4}{|c|}{ M a r k e r RYRl } \\
\hline Genotype & $N N$ & $\mathrm{Nn}$ & $n n$ \\
\hline in conventionally western cluster & 100,0 & 0,0 & 0,0 \\
\hline in eastern cluster & 100,0 & 0,0 & 0,0 \\
\hline \multicolumn{4}{|c|}{ M a r k e $E S R$} \\
\hline Genotype & $A A$ & $A B$ & $B B$ \\
\hline in conventionally western cluster & 100,0 & 0,0 & 0,0 \\
\hline in eastern cluster & 100,0 & 0,0 & 0,0 \\
\hline \multicolumn{4}{|c|}{$\mathrm{M}$ a rke r $F S H B$} \\
\hline Genotype & $A A$ & $A B$ & $B B$ \\
\hline in conventionally western cluster & 32,9 & 26,6 & 40,5 \\
\hline in eastern cluster & 0,0 & 50,0 & 50,0 \\
\hline \multicolumn{4}{|c|}{$\mathrm{M}$ a r k e r $N C O A I$} \\
\hline Genotype & AlAI & $A 1 A 2$ & $A 2 A 2$ \\
\hline in conventionally western cluster & 87,5 & 12,5 & 0,0 \\
\hline in eastern cluster & 0,0 & 0,0 & 100,0 \\
\hline \multicolumn{4}{|c|}{$\mathrm{M}$ a rke r $B F$} \\
\hline Genotype & $A A$ & $A B$ & $B B$ \\
\hline in conventionally western cluster & 1,4 & 1,4 & 97,3 \\
\hline in eastern cluster & 0,0 & 28,6 & 71,4 \\
\hline \multicolumn{4}{|c|}{$\mathrm{M}$ a rke r $M U C 4$} \\
\hline Genotype & $C C$ & $C G$ & $G G$ \\
\hline in conventionally western cluster & 100,0 & 0,0 & 0,0 \\
\hline in eastern cluster & 100,0 & 0,0 & 0,0 \\
\hline \multicolumn{4}{|c|}{ M a r k e $I G F 2$} \\
\hline Genotype & $Q Q$ & $Q q$ & $q q$ \\
\hline in conventionally western cluster & 100,0 & 0,0 & 0,0 \\
\hline in eastern cluster & 100,0 & 0,0 & 0,0 \\
\hline \multicolumn{4}{|c|}{$\mathrm{M}$ arke r $M C 4 R$} \\
\hline Genotype & $A A$ & $A G$ & $G G$ \\
\hline in conventionally western cluster & 0,0 & 2,5 & 97,5 \\
\hline in eastern cluster & 0,0 & 0,0 & 100,0 \\
\hline \multicolumn{4}{|c|}{$\mathrm{M}$ arke $\mathrm{r} P O U 1 F 1$} \\
\hline Genotype & $C C$ & $C D$ & $D D$ \\
\hline
\end{tabular}




$\begin{array}{lccc}\text { in conventionally western cluster } & 0,0 & 0,0 & 100,0 \\ \text { in eastern cluster } & 0,0 & 22,2 & 77,8 \\ & \text { M a r k e r ECRF18/FUTI } & A G & G G \\ \text { Genotype } & A A & 0,0 & 100,0 \\ \text { in conventionally western cluster } & 0,0 & 0,0 & 100,0 \\ \text { in eastern cluster } & 0,0 & \end{array}$

The authors compared frequencies of genotypes and alleles for the mentioned DNA markers in tested animals (Table, Fig. 2). Five of the 10 studied DNA markers (RYR1, ESR, MUC4, IGF2, ECRF18/FUT1) were found to be monomorphic in both territorial clusters. Therefore, mutations that caused this genetic polymorphism have occurred after domestication of pigs. Conventionally western and eastern clusters showed insignificant intergroup differences in the frequency of alleles of DNA markers: FSHB (p $\mathrm{p}_{\mathrm{A}}-$ respectively, 0,462 and 0,250), $B F\left(\mathrm{p}_{\mathrm{A}}-0,020\right.$ and 0,143$), M C 4 R\left(\mathrm{p}_{\mathrm{A}}-0,013\right.$ and 0,000$)$, and POU1F1 ( $\mathrm{p}_{\mathrm{C}}-0,000$ and 0,111$)$.

The studied territorial groups had reliable differences in the frequency of $N C O A 1$ allele: in the first cluster $\mathrm{p}_{\mathrm{A} 1}=0,938$, in the second cluster $\mathrm{p}_{\mathrm{A} 1}=0,000$. The presence of $A 2 N C O A 1$ allele in the conventionally western cluster of wild boar can be seen as a result of introgression from Chinese pigs in XVII-XIX centuries (15). At the same time, the occurrence of $A 2$ allele in domestic pigs with a frequency of 0,722 to 1,000 (21) means the possibility of its introduction through hybridization with domestic pigs.

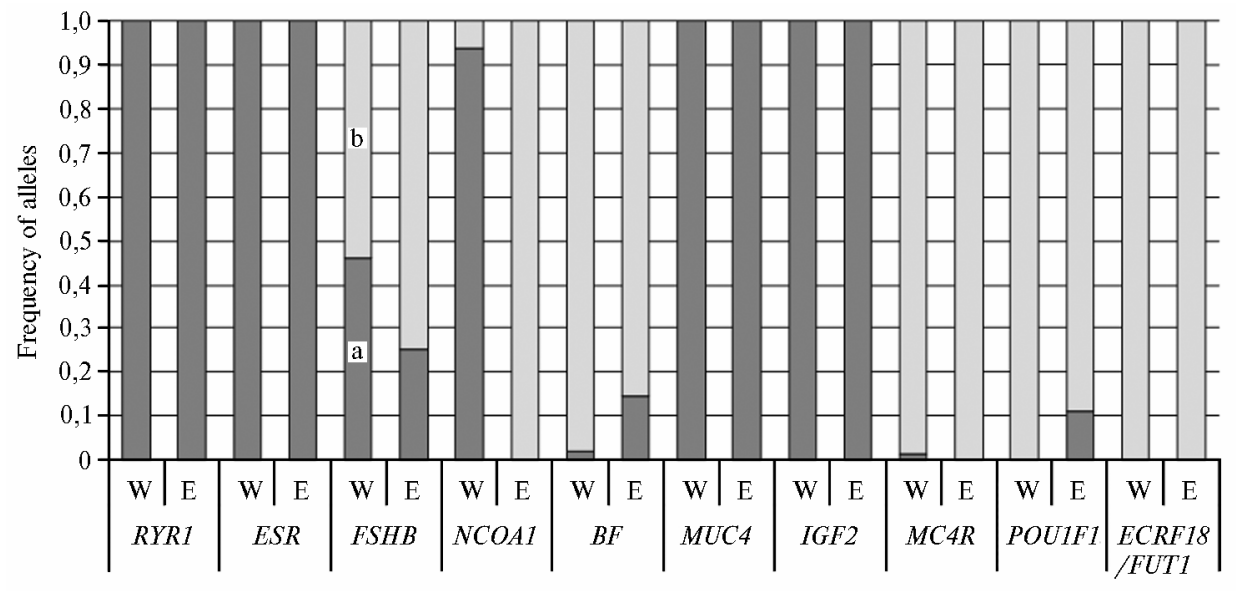

Fig. 2. Frequency distribution of alleles of DNA-markers QTL in wild boar (Sus scrofa $\mathrm{L}$., 1758) in western (W) and eastern (E) territorial clusters: $\mathrm{a}, \mathrm{b}$ - alleles 1 and 2, respectively. Allele $1-N$ for $R Y R 1, A$ for $E S R, A$ for $F S H B, A 1$ for $N C O A 1, A$ for $B F, C$ for $M U C 4, Q$ for $I G F 2, A$ for $M C 4 R, C$ for $P O U 1 F 1, A$ for ECRF18/FUT1; Allele $2-n$ for $R Y R 1, B$ for $E S R, B$ for $F S H B, A 2$ for $N C O A 1, B$ for $B F, G$ for $M U C 4, q$ for $I G F 2, G$ for $M C 4 R, D$ for POU1F1, G for ECRF18/FUT1.

So, the examined populations of wild boar Sus scrofa differ in both anonymous DNA-markers and certain genes associated with quantitative trait loci in porcine genome.

\section{REFERENCES}

1. Groves C. Ancestors for the pigs: taxonomy and phylogeny of the genus Sus. Research School of Pacific Studies, Australian National University. Canberra, Australia, 1981.

2. Heere W., Rohrs M. Zoological considerations on the origins of farming and domestication. In: Origins of agriculture /C.A. Reed (ed.). Mouton, The Hague, 1977: 245-279.

3. Epstein H. Pig. In: Evolution of domesticated animals /I.L. Mason (ed.). Longman, London, 1984: 145-162.

4. Danilkin A.A. Svinye (Seriya «Mlekopitayushchie Rossii i sopredel'nykh regionov») [Suidae: Mammals of Russia and Adjacent Regions]. Moskva, 2002.

5. Pavlov M.P. Akklimatizatsiya okhotnich'e-promyslovykh zverei i ptits v SSSR [Acclimatization of Game Mammals and Birds within the USSR]. Kirov, 1999.

6. Pavlov M.P., Korsakova I.B., Lavrov N.P. Akklimatizatsiya okhotnich'e-pro-myslovykh zverei i ptits $v$ SSSR [Acclimatization of Game Mammals and Birds within the USSR]. Kirov, 1974.

7. Li Kh., Min M.S., Kim K.S., An Dzh., Li M.E. Materialy nauchno-prakticheskoi konferentsii, posvyashchennoi 75-letiyu Lazovskogo zapovednika [Proc. Sci.-Pract. Conf. to the 75th Anniversary of Lazovsky Nature Reserve]. Vladivostok, 2010: 153-158.

8. Varnakov A.P., Dankvert S.A., Davydova E.E., Davydov A.V., Soltynskaya I.V., Seliverstova A.S., Ignatova I.A., Pronyaev A.V., Vol'f S.A., Soinova O.L., Markov N.I., Rozhkov Yu.I. Vestnik okhotovedeniya, 2011, 8(2): 173-178.

9. Kim Sung Kiong, Li Kiang Seok, Markov N.I., Varnakov A.P., Dankvert S.A., Pronyaev A.V., Davydov A.V., Rozhkov Yu.I. Vestnik okhotovedeniya, 2012, 9(2): 209-214.

10. Fang M., Andersson L. Mitochondrial diversity in European and Chinese pigs is consistent with population expansions that occurred prior to domestication. Proc. the Royal Society B: Biological Sciences, 2006, 273: 1803-1810.

11. Gladyr' E.A., Ernst L.K., Kostyunina O.V. Sel'skokhozyaistvennaya Biologiya [Agricultural Biology], 2009, 2: 16-26.

12. Fang M., Larson G., Soares Ribeiro H., Andersson L. Contrasting mode of evolution at a coat color locus in wild and domestic pigs. PLoS Genetics, 2009, 5: 1-6.

13. Koutsogiannouli E.A., Moutou K.A., Sarafidou T., Stamatis C., Mamuris Z. Detection of hybrids between wild boars (Sus scrofa scrofa) and domestic pigs (Sus scrofa f. domestica) in Greece, using the PCR-RFLP method on melanocortin-1 receptor (MC1R) mutations. Mammal. Biol., 2010, 75 : 69-73.

14. Ojeda A., Huang L.S., Ren J., Angiolillo A., Cho I.C., Soto H., Lemus-Flores C., Makuza S.M., Folch J.M., Perez-Enciso M. Selection in the making: a worldwide survey of haplotypic diversity around a causative mutation in porcine IGF2. Genetics, 2008, 178: 1639-1652.

15. Giuffra E., Kijas J.M.H., Amarger V., Carlborg O., Jeon J.-T., Andersson L. The origin of the domestic pig: independent domestication and subsequent introgression. Genetics, 2000, 154: 1785-1791.

16. Kuryl J., Zurkowski M., Urbanski P., Wyszynska-Koko J. Distribution of the polymorphic variants of genes RYR1, LEP, GH, MYOG, MYF5, and GDF8 in wild boars from North-East of Poland. Animal Science Papers and Reports, 2004, 22(3): 271-278.

17. Zinov'eva N.A., Gladyr' E.A. Dostizheniya nauki i tekhniki APK, 2011, 9: 19-20.

18. Pritchard J.K., Stephens M., Donnelly P. Inference of population structure using multilocus genotype data. Genetics, 2000 , 155: $945-959$.

19. Veir B. Analiz geneticheskikh dannykh /Perevod s angliiskogo D.V. Zaikina, A.I. Pudovkina, A.N. Tatarenkova [Genetic Data Analysis]. Moskva, 1995.

20. Zhivotovskii L.A. Populyatsionnaya biometriya [Population Biometry]. Moskva, 1991.

21. Zinov'eva N.A., Kostyunina O.V., Gladyr' E.A., Bannikova A.D., Kharzinova V.R., Larionova P.V., Shavyrina K.M., Ernst L.K. Zootekhniya, 2010, 1: 8-10. 